\title{
Parliamentary information sources, systems and services in South Africa
}

\author{
Janneke B. Mostert \\ Department of Library and Information Science, University of Zululand, XI00I, \\ KwaDlangezwa 3886, South Africa \\ jmostert@pan.uzulu.ac.za
}

\begin{abstract}
Received: $10^{\text {th }}$ April 2004
Revised: $20^{\text {th }}$ July 2004

Parliamentarians need accessible, current and authoritative information for decision-making. However, within the African continent information sources, systems and services are not always well organized and accessible. South Africa, relatively speaking has a well-organized information sector making a variety of information sources, systems and services available to the parliamentarian. The aim of the paper is to discuss the information needs of the South African parliamentarians, what sources they use to access information, and explore what the information sector in South Africa can provide to satisfy their information needs. The information for writing this paper was gained through a literature review, interviews, and an empirical study. The study targeted all the South African parliamentarians, and a questionnaire was used to gain information from the respondents. One hundred and sixty seven (23\%) responses were received. The parliamentarians expressed a variety of information needs. Although the predominant preference source of information was still for printed sources (78\%), the use of electronic sources (24\%) was notable, taken into account its recent introduction. A myriad of information sources, and systems and services are available to the parliamentarian, either by visiting the information provider in person, or via telephone, faxing, visiting a website or e-mail. The parliamentarians however do not always make time or have the skills to access the information sources. It is strongly recommended that the services of a professionally trained information intermediary such as a parliamentary librarian be used to gate keep the information overload and provide the parliamentarian with the needed information. The increasing use of non-professional information providers such as Personal Assistant should be minimized and further investigated.
\end{abstract}

Keywords: Parliamentary Information Sources: Parliamentary Information Systems: Parliamentary Information Services: South Africa

\section{Introduction}

Effective governance of a democracy is highly reliant on effective information provision to assist parliamentarians in their decision-making and support democratic principles enshrined in the constitution of the country (Mostert, 2004). For information to be beneficial to the decision-making process of a country, it firstly needs to be available, and secondly, to be reliable. Adeyemi (1991) observes that in many African countries information sources, services and systems have become highly segmented, divisive and uncoordinated, thus affecting the availability of information for public exploitation. As effective decision-making relies on relevant information lack of information influences accurate decision-making negatively. In this regard Alemna and Skouby (2000), Marcella, Carcary and Baxter (1999) and Serema (1999) emphasize that there is a close relationship between the sustenance of a democracy and the ability of the parliamentarians to access and effectively utilize information.

A variety of information sources, systems and services that can provide information to parliamentarians do exist in Africa. Information sources, systems and services can be defined in several ways. For example, Behrens (2000:5) defines information sources as "objects or entities that communicate facts". An information system is described as "a discrete set of information resources organized for the collection, processing, maintenance, transmission, and dissemination of information, in accordance with defined procedures, whether automated or manual. (GILS 1994:I). It widely known that a system is a whole consisting of parts that are integrated, interdependent and often synchronized to perform a given function for achieving specific objectives. Information services are "programs that provide for the collection, classification, storage, retrieval and dissemination of recorded knowledge for the community. Included are computer bulletin boards, information and referral programs, information lines, library services, media services, public awareness/education, campaigns, research data and rumor control activities" (Door online n.d.:I). Information service should also be simply defined as a unit designed to provide information.

Kaniki (1992) and Bredenkamp (1995) identify various information providers active in Africa, for example all types of information channels/media as well as a variety of information services and systems such as individuals, agencies, organizations, institutions or groups of institutions. Bredenkamp (1995) points out that these sources are of specific importance in accessing accurate and current information. Behrens (2000) points out that government are major producers, publishers and processors of information in a country, particularly the kind of information needed for effective governance. However, the majority of government information sources are in the form of grey literature, compounding the problems of accessibility and bibliographic control. A literature survey on information access and bibliographic control 
in Africa indicates that widespread problems with access, bibliographic control and the orderly dissemination of information through information providers render information inaccessible to users (Faye 1995; Mchombu 1993; Mostert 1997; Otike 1989; Sturges and Neill 1990).

South Africa is in the fortunate position of having a well-developed information sector providing access to a myriad of different information sources, systems and services. Britz, Boon and De Lange (1993) describe the information sector as those organisations and individuals concerned with the following activities in relation to the information cycle: collection, storage, organization, processing, tracing and provision of information on behalf of another person or organization (1993:62). Boon in De Lange, Boon and Britz (1993:62) differentiates between broad categories within the information sector:

- The sector concerned with inventing, generating and collecting knowledge which, if transmitted is information for the recipient (including scientists, knowledge workers and collectors of data)

- The sector concerned with the packaging, storage, organization, recall and duplication of information (e.g. publishing and printing, libraries, documentation centres, information services, database brokers and archives)

- The sector concerned with the dissemination of information (e.g. the mass media, including radio, television and newspapers, books, journals, libraries, information centres and information brokers)

- The sector concerned purely with information technology (computers and telecommunications that create infrastructure).

To find information, parliamentarians can exercise several options, i.e. to use the information services/systems dedicated to providing information to them, such as the parliamentary libraries and the Government Communication Information Services (GCIS), or alternatively they could exploit the diverse information sector. It should however be pointed out that availability of sources in the information sector does not necessarily imply knowledge of these sources or ready accessibility to them.

This article will attempt to highlight what information needs have been expressed by parliamentarians, and explore the sources, services and systems they currently use to satisfy their information needs. As the parliamentarians are not always knowledgeable on what information resources are available a further aim of the paper is to represent the information sources, services and systems potentially available to parliamentarians. The sources, systems and services will be grouped according to the categories identified by Boon (1993), though it should be noted that a duplication of systems and services takes place between sector two and three.

\section{Procedures}

Two approaches were used in the paper. In the first instance an empirical study was conducted to determine the information needs experienced by the parliamentarians, and also to determine what kind of information sources, services and systems they currently use to try and satisfy these needs. The study was conducted amongst all the South African parliamentarians, both at national and provincial level. A total of 763 questionnaires were sent and 167 returned, giving a return rate of $23 \%$. Questionnaires were deemed to be the most practical tool for obtaining information, since it was proved during the early stages of the study that direct access to parliamentarians was not always possible. For example, the research assistant tried on numerous occasions to contact parliamentarians individually in the National Assembly, but was refused entry to the premises. Their busy daily schedules were another factor mitigating towards the use of questionnaires. Follow-up work was done by way of posted reminders. (It should be noted that only a section of the results of this study is being reported in this article. The full results of the study will be reported in the next issue of this journal).

The information was gathered using a literature survey, interviews and the Internet. The literature review involved scanning current literature that could shed light on the available information sources, services and systems in South Africa. In this regard the South African yearbook was a valuable source to use. Interviews were conducted with staff members at the Library of Parliament in Cape Town, as well as with the librarian of the Pietermaritzburg branch of the KwaZulu/ Natal legislative library. This provided insight into the functioning of parliamentary information services. The Internet was used to search for literature, but also to do an exploratory search on the available information sources, systems and services in South Africa. The Internet was searched according to the broad categories as identified by Boon (1993). This was done by visiting and surveying specific websites. The websites visited provided specific detail as to what information sources, systems and services are available and it also provided detail on the accessibility of these sources, systems and services in electronic format. 

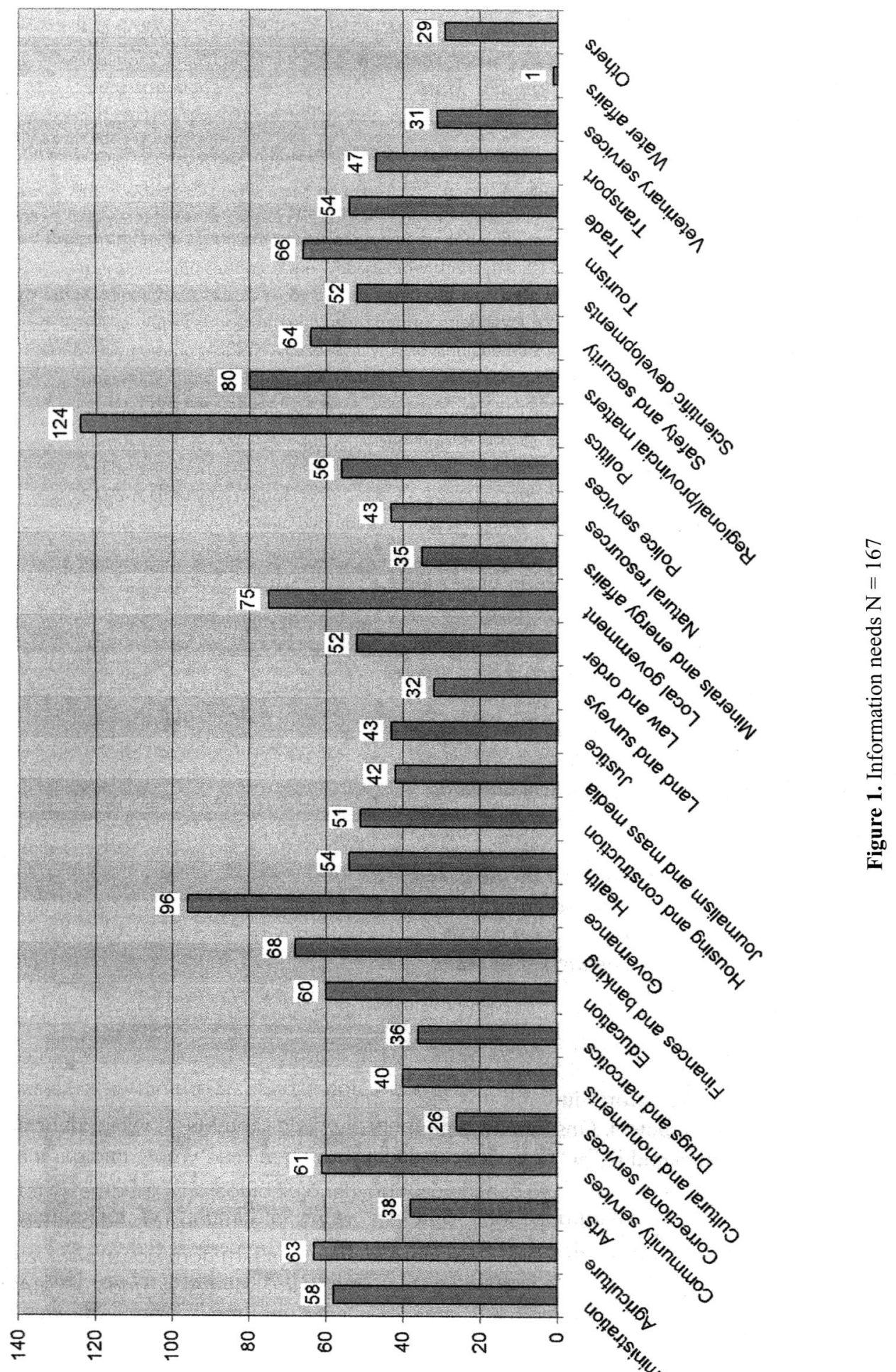


\section{Information needs of South African parliamentarians}

An empirical study done by Mostert (2004) on the information needs of parliamentarians indicated that issues concerning governing and politics were in the highest demand. A variety of other topics (indicated in Figure I) was also identified, though demand for information on such issues seems to be more interest-based due to their respective portfolio's or participation in committees dealing with the issues. Other strong triggers for expressing an information need were closely related to performance within the parliamentary structures, for example to participate in parliamentary debates (82\%), or to be able to make a speech on a topic $(78 \%)$.

\section{Information sources/systems used to satisfy information needs}

Parliamentarians have a variety of information sources and systems at their disposal that can be used to access information. The study done by Mostert (2004) revealed the preferences indicated by the parliamentarians in Table I. The sources have been grouped together into four main categories, i.e. print-based sources, electronic sources, information systems and oral sources.

Table 1 Information sources/systems used, $\mathrm{N}=167$

\begin{tabular}{|c|c|c|c|c|c|c|c|c|c|}
\hline Sources/systems & Often & $\%$ & Seldom & $\%$ & Never & $\%$ & NO RESPONSE & $\%$ & Total \\
\hline \multicolumn{10}{|l|}{ Print-based sources } \\
\hline Books & 109 & 65 & 28 & 17 & 24 & 14 & 6 & 4 & 167 \\
\hline Journals & 80 & 48 & 39 & 23 & 42 & 25 & 6 & 4 & 167 \\
\hline Newspapers & 133 & 80 & 11 & 7 & 17 & 10 & 6 & 4 & 167 \\
\hline Magazines & 80 & 48 & 40 & 24 & 41 & 25 & 6 & 4 & 167 \\
\hline Governmental publications & 101 & 60 & 33 & 20 & 27 & 16 & 6 & 4 & 167 \\
\hline \multicolumn{10}{|l|}{ Electronic sources } \\
\hline Internet & 84 & 50 & 22 & 13 & 55 & 33 & 6 & 4 & 167 \\
\hline Digital libraries on the Internet & 30 & 18 & 32 & 19 & 99 & 59 & 6 & 4 & 167 \\
\hline Virtual libraries on the Internet & 20 & 12 & 29 & 17 & 112 & 67 & 6 & 4 & 167 \\
\hline On-line databases & 25 & 15 & 25 & 15 & 111 & 66 & 6 & 4 & 167 \\
\hline Electronic journals on the internet & 73 & 44 & 33 & 20 & 55 & 33 & 6 & 4 & 167 \\
\hline Electronic newspapers & 62 & 37 & 38 & 22 & 61 & 37 & 6 & 4 & 167 \\
\hline \multicolumn{10}{|l|}{ Information systems } \\
\hline Government Departments & 79 & 47 & 47 & 28 & 35 & 21 & 6 & 4 & 167 \\
\hline NGO's & 44 & 26 & 58 & 35 & 59 & 35 & 6 & 4 & 167 \\
\hline Parliamentary library & 56 & 34 & 56 & 34 & 49 & 29 & 6 & 4 & 167 \\
\hline Public library & 18 & 11 & 51 & 31 & 92 & 55 & 6 & 4 & 167 \\
\hline Embassies & 16 & 10 & 44 & 26 & 101 & 60 & 6 & 4 & 167 \\
\hline National archives & 15 & 9 & 43 & 26 & 103 & 62 & 6 & 4 & 167 \\
\hline \multicolumn{10}{|l|}{ Oral sources } \\
\hline Parliamentary colleagues & 57 & 34 & 44 & 26 & 60 & 36 & 6 & 4 & 167 \\
\hline Individuals in the private sector & 40 & 24 & 52 & 31 & 69 & 41 & 6 & 4 & 167 \\
\hline Individuals in the public sector & 45 & 27 & 41 & 25 & 75 & 45 & 6 & 4 & 167 \\
\hline Chiefs/indunas & 11 & 7 & 21 & 13 & 129 & 77 & 6 & 4 & 167 \\
\hline
\end{tabular}

The strong preference for print-based sources $(78 \%)$ is still apparent though utilization of electronic access (24\%), taking into account the "newness" of the source, has shown notable growth as well.. It is interesting to note relatively poor support for oral sources (33\%), which is in contrast with a finding made by Thapisa (1996) amongst parliamentarians in Botswana. 


\section{Information sources, systems and services in South Africa}

\subsection{Sector concerned with inventing, generating and collecting knowledge}

Parliamentarians are expected to be abreast of the latest developments in science, technology and social sciences. To gauge public feeling they also need to conduct, or commission the conducting of, opinion polls. In South Africa many such research organisations and information brokers exist (a search on the Internet on 26/02/04 revealed 202,000 hits), specializing in a number of fields. Three major research institutions are currently the leaders in the creation and dissemination of original and current research i.e. the Council for Science and Industrial Research (CSIR) (www.csir.co.za) and the HSRC (Human Sciences Research Council) (www.hrsc.ac.za) and Markinor (www.markinor.co.za). All three companies are regularly commissioned by the government to perform research on a variety of issues and topics. Information is disseminated by way of media releases, published reports, or by publishing the information on their respective WebPages. Information providers within the organizations can be contacted either by telephone, fax or via electronic means.

\subsection{Sector concerned with the packaging, storage, organization, recall and duplication of information}

\section{Publishing and printing}

According to Burgers (2003) the technical handling of print rates amongst the best in the world. Hendrikz (n.d) observes that the South African publishing industry is characterized a variety of publishers, ranging from big to medium sized to small publishers. Based on annual publication, the Directory of South African Publishers (1998/99) revealed that 2,95। publishers were active during that year. This list varies from year to year depending on active publishing during a year. The list of major South African publishers supplied in The Europa World Yearbook 200I (2001:3596-7) indicates that a variety of materials are published on a wide range of topics including educational, general materials, biographies, history, Africana, reference materials, school textbooks, law, financial matters, art, religious materials, materials in all the different languages used in South Africa, and so on. Publication of all official publications of government and provincial departments, as well as local authorities, is the responsibility of the Government Printer of South Africa. During 1999/ 2000 they handled 6,267 print orders (Hendikz, n.d).

On-line bookshops are available on the Internet. The most popular South African-based on-line bookshop is Kalahari.net (http://www.kalahari.net) (Hendrikz, n.d). This website allows transactions in books, magazines, DVD/CDs, Software, videos and games. It also provides access to the Van Schaiks on-line bookshop which specialises in tertiary materials and materials on continuing professional development. Other well-known on-line bookshops are:

- Amazon.com (http://amazon.com) providing access to information materials worldwide,

- Shuter and Schooter (http://www.shuter.co.za) publishing educational and materials of a general nature, as well as materials in African languages,

- Juta (http://www.juta.co.za) specialising in academic, general, law and electronic materials,

- Heinemann (http://heinemann.co.za) publishing local content textbooks and imported textbook from Heinemann in the United Kingdom,

- Butterworth Publishers (http://butterworths.co.za) specialising in materials on tax, law and accountancy

- Tafelberg (http://www.tafelberg.com) selling materials for juveniles, fiction and non-fiction, arts and crafts, nature and tourism (The Europa World Yearbook, 200I).

Retail bookshops are found in most major towns and cities in South Africa. Hendrikz (n.d) indicates that in a survey done of the Braby's Commercial Directory for the three cities, Johannesburg, Cape Town and Pretoria revealed in excess of 180 retail bookshops. The most well-known is the Central News Agency (CNA), while other chain stores like PNA (Pen \& Art) and Exclusive Books also offer services in all the major cities. Several independent bookstores can be found in smaller towns. However there is still a paucity of bookstores in townships.

\section{Libraries/Information centres}

The Library and information services sector provides access to approximately 1249 libraries in the country, including a national library, public libraries, provincial library services, special libraries, government libraries, school libraries, university and college libraries. Included is the South African Library for the Blind located in Grahamstown, catering for the needs of the blind and visually impaired. Acting as a national library and information service, it provides audio and Braille books in seven South African languages free of charge (Burger, 2002).

Special libraries belonging to private companies, government departments as well as private individuals are normally not open to the general public, but many participate in the Southern African Interlending Scheme (SAIS), thus making their materials available and accessible.

Currently, 36 University, Technikon and College Libraries are available, but will be reduced to 22 institutions under the National Plan for Higher Education(200I). Most academic libraries are accessible to their primary clients, i.e. the 
students and management of a particular institution, as well as to community members by prior arrangement with Library staff. All academic libraries participate in SAIS (Hendrikz, n.d).

The Legal Deposit Act of 1997 (Act 54) regulates the legal deposit in South Africa, the purpose of which is to see to it that the country's intellectual and cultural heritage is preserved, collected, bibliographically controlled and made available to present and future generations (Beherens 2000). The five Legal Deposit Libraries include the National Library of South Africa (NLSA), the Library of Parliament in Cape Town, the Natal Society Library in Pietermaritzburg, the Bloemfontein Public Library and the National Film, Video and Sound Archives in Pretoria. Since legal depositors are required to deposit copies within fourteen days of publication, these libraries are in possession of the most recently published materials in the country (Behrens, 2000). Materials in all formats, ranging from books and journals to CD-ROMs, videos, microfilms and digital formats are subjected to Legal Deposit (Burger, 2002)

The NLSA, with a division in Pretoria and one in Cape Town, consists of a collection of rare and contemporary materials, donations from various benefactors reflecting both the colonial and indigenous heritage of the nation, as well as special collections of photographs, news clippings, Africana manuscripts, rare maps and atlases and an art collection. Materials can be accessed by visiting the libraries during office hours. If an individual is not able to visit either of the Libraries the website http.www.nsla.ac.za provides access to their Online Public Access Catalogue (OPAC), access to the reference service offered by a reference librarian, as well as a document delivery service. Alternatively, information requests can be e-mailed, faxed or telephoned through (Burger, 2002).

The Library of Parliament, Cape Town, provides access to a book stock of approximately 96506 books, all official publications dating back to 1910, and in some cases even further back, audio-visual materials, newspapers, journals, those subscribed to and those received through legal deposit, Internet access, on-line databases, and databases on CD-ROM (Burgers, 2003). The parliamentarians using the Provincial Parliamentary Legislatures are provided with access to a small book collection, newspapers and journals, with a variety of information services (Clinton-Parker 2002).

Access to the information sources stored within the majority of South African Libraries can be obtained via the interlibrary loan system available in South Africa, a system in which the Library of Parliament, Cape Town, and the Provincial Legislative Libraries participate.

The Pretoria division of the NLSA coordinates the Southern African Interlending Scheme (SAIS). This countrywide scheme allows the approximate 700 southern African libraries and other organizations affiliated to the scheme to share resources with each other. Requests are met by supplying the required book, or a copy of the article from the local library (Burger, 2002). All participating libraries contribute to a union catalogue, SACat, to make their holdings known to the other members. All libraries participating to the union catalogue can enter a request either manually through the NLSA, or if they subscribe to the South African Bibliographic and Information Network Online (SABINET Online) requests can be posted on-line through their ReQuest service (Behrens, 2000).

Archives and record centres/Museums

Archival collections consist mostly of official information sources relating to the activities of a formal organisation like a government, business, institution, individual or society (Behrens, 2000). The preservation of archival material in South Africa is regulated by the National Archives of South Africa Act, no. 43 of 1966. The law specifies that official records should be sent to the National Archives after 20 years (Hendrickz, n.d).

Archives abound in South Africa, covering varied topics, ranging from political figures and parties like Nelson Mandela, Thabo Mbeki, Steve Biko and the ANC, contemporary history, Africana, newspaper archives, popular memory, religious materials, pictures of news, sport, personalities and wildlife, language, government documentation, and so on. A search on the Internet reveals a wide selection of the archives available. Through the Internet, access to collections can in most cases be secured.

The official archive in South Africa is the National Archives of South Africa (NASA) with repositories in Pretoria, Johannesburg, Durban, Port Elizabeth, Cape Town, Bloemfontein and Pietermaritzburg, and record centres in Johannesburg and Pretoria.

To use an archive repository, a visit can be paid in person, or alternatively a request for assistance can be phoned through or sent by mail. In the last two instances, in-depth assistance cannot be rendered. In some cases private researchers can be used to retrieve the correct information. Office hours are observed from Monday to Friday, but on arrangement the Archives can extend their hours during the day or weekend (Calitz, n.d.). Access to the computerised database of holdings in the National Archives can be gained through the National Automated Archival Information

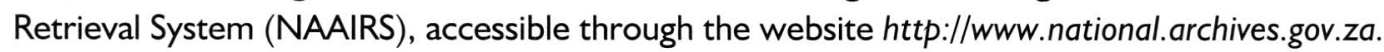

The National Film, Video and Sound Archive (NFVSA), situated in Pretoria is a Legal Deposit institution, storing audiovisual and related materials made about South Africa. By visiting the reading room materials can be accessed. Materials 
need to be booked three days in advance before utilisation is allowed. Contact information to this Archives is given on the NASA website or in a telephone directory.

Museums abound in South Africa, as is testified to by the fact that most cities and towns boast a museum or museums of some sorts, either to preserve local history or to provide information on a topical subject. Museums are generally open to the public during office hours. Alternatively, access can be gained through the Internet.

\section{Non-Governmental Organisations}

Non-Governmental Organizations (NGO's) are a source of grassroots level information. NGO's can be traced in telephone directories, but also on the Internet. A search on the search engine Ananzi.com reveals a large number of NGO's available on the Internet. A good example is the website $h t t p: / / w w w . t z a n e e n . c o . z a / g o v . h t m$, which lists not only local NGO's but also international ones. The individual websites normally provide background information about the NGO, services or programmes offered, publications, if any, and contact information.

\section{Embassies}

Foreign embassies are providers of information concerning their countries of origin. Parliamentarians often need information relating to those countries to allow for comparative studies with South African issues. Embassies can provide contact details to a host of government officials, organisations and institutions in their country, publications, information on legislation and policies, and so on. To establish contact the telephone directory can be used, or alternatively the GCIS website at (http://cgis.gov.za/docs/directories/index.html) provides a Directory of Contacts.

\section{Commercial Database Industry}

In South Africa many local databases are produced, but international databases are also available. The databases are available electronically as CD-ROMs or as online databases. Access can either be sold, free or available on subscription (Behrens, 2000).

Two well-known database services available in South Africa are the National Information Services Corporation (NISC) and SABINET Online.

The National Information Services Corporation is a United States based publishing company with a branch in South Africa. To distinguish the South African branch, it is known as the National Inquiry Services Centre (NISC SA). The NISC SA provides access to all databases produced internationally by NISC worldwide, as well as producing databases of local and African resources. South African databases available through NISC SA (http://www.nisc.com) include: South African Studies, African Studies, African health anthology, Water resources worldwide, Fish and fisheries worldwide, African agriculture and business and South African magazines and periodicals (Behrens, 2000).

SABINET Online provides access to over I 000 different bibliographic and full-text databases. As a subscriber to SABINET Online the Library of Parliament provides the parliamentarian with access to this service. A search on the website (http://www.sabinet.co.za) identifies a number of appropriate databases tailor-made for the information needs of the parliamentarian. This includes databases like:

- Bill Tracker: Supplies full details, present status and full-text of every Bill tabled before Parliament. In conjunction with the SA Gazettes database, which contains the full-text of all acts, amendment acts and regulations, they provide a onestop service on legislation.

- Legilink Monitoring Services: Provides e-mail service notifying users about parliamentary information impacting on their business.

- SA Legal: Provided in conjunction with Jutalaw and includes the SA Statutes and Daily Law Reports

- SA News: Full-text research material from the major news media. Provides access to SA Media and SAPA - both databases covering the daily news, with SA Media also providing access to archived materials

- SA Tenders: provides information on current tenders

- Legilink Financial Round-up services: weekly e-mail service alerting users on forthcoming and current financial legislation and policies. Provides links to relevant full-text documents.

- Netlaw: Provides access to more than 486 acts with rules, regulations and forms that have been enacted since 1994.

- Ingenta: a periodical index database and article delivery service covering 12 million articles from $17000+$ journals.

- SA ePublications: provides full-text articles from South African published journals, online

- SACat Plus: Provides access to the following databases:

- SACat: Computerised database of all library stock in Southern Africa. Includes books, journals, conference proceedings, standards, and technical reports.

- SANB: Database containing a list of books, pamphlets, government publications, microforms, maps, technical reports, and periodicals published in South Africa.

- Book Data: Information on in-print, new and forthcoming titles

- UCTD: Bibliographic records of theses and dissertations at Masters and Doctorate level in South African Universities 
since 1918.

- Navtech: Current and completed research projects undertaken at Technikons

- Subsidie: List of all periodicals approved as research platforms.

- Current and Completed Research: South African research projects in the field of economics, science, and humanities.

- Fiction: List of fiction available in printed, braille and sound format.

- SA Citations Plus: covers national and international information by indexing records from journal articles, research reports, conference proceedings and chapters in books. It includes the following databases:

- Index to South African Periodicals (ISAP): Indexed articles from more than 600 S.A. periodicals

- Kovsidex: Selected articles on a wide range of reference works on the theory and practice of education

- Forestry: a pamphlet collection from forestry, wood science and nature conservation research institutes, locally and internationally

- Centre for Rural Legal Study: Focus on agriculture and agricultural workers on commercial farms in S.A.

- CLOVERDEX: indexed periodical articles collected by CLOVER (Sabinet Homepage, 2003).

Other databases of note are EBSCO Information Services, Elseviers Science, Swets and Blackwells, Bowker-Saur, ISI, Kluwer Academic Publishers and HW Wilson. Vendor specialising in producing information in CD-ROM format, and making it available via the Internet, includes CD-ROM Information, Silver Platter and The Dialog Corporation (Behrens, 2000).

\subsection{Sector concerned with the dissemination of information}

Mass media

A vigorous mass media sector exists in South Africa, consisting of broadcasting services, including radio and television, newspapers and magazines.

\section{Broadcasting}

The major broadcasting corporation is South Africa is the South African Broadcasting Corporation (SABC), which controls both radio and television services on a national and a local level. National services include a twenty-four hour radio service with stations broadcasting in English and Afrikaans. Domestic services are offered on a regional basis and include services like Radio South Africa, Afrikaans Stereo, Radio 5, Radio 2000, Highveld Stereo, Good Hope Stereo, Radio Kontrei, RPN Stereo, Jacaranda Stereo, Radio Algoa, Radio Lotus, Radio Metro, Radio Lebowa, Radio Ndebele, Radio Sesotho, Setswana Stereo, Radio Swazi, Radio Tsonga, Radio Xhosa and Radio Zulu. An external service is also offered i.e. Channel Africa Radio. This service broadcasts 217 hours a week in English, Kiswahili, Portuguese and several other African languages (The Europa World Yearbook, 2001:3597).

SABC television operates television services in seven languages over three channels (The Europa World Yearbook, 2001 ). A private subscription television service was launched in 1986, and has currently 1.23 million subscribers from 41 countries across Africa. Consisting of two channels, the main channel focuses on movies and sport, but also offers children's programmes, series and magazine programmes. For a two hour period between 17:00 and 19:00 everyday unencoded programmes are available to all viewers. The second channel, Community Services Network, offers sports programmes, as well as community channels for Indian, Portuguese, Italian and Christian communities (Burger, 2002).

Digital satellite broadcasting is offered by Multichoice Africa. Currently the service is offered to I.4 million subscribers in over 50 countries on the African continent. This services offers over 54 video and 48 music channels (Burger, 2002).

The free-to-air television service, e.tv, a free commercial service reliant on advertising, started broadcasting in October 1998. It offers a 24-hour service and news broadcasts (Burger, 2002).

\section{Newspapers and magazines}

Various newspapers are published, ranging from national to regional to local newspapers, as well as the free "knock and drop" types (Behrens, 2000). Because of the geographic size of the country a true daily national does not yet exist, except for the four Sunday newspapers (Sunday Times, Rapport, Sunday Independent and Sunday Sun), and the weekly newspaper City Press (Burger, 2002).

Seventeen dailies, seven Sunday papers and 21 weeklies are published in South Africa. About 158 community papers are printed on a weekly basis providing news on local events. The majority of the papers are published in either Afrikaans or English, however in 2002 an isiZulu newspaper Isolezwe was launched in KwaZulu-Natal (Burger, 2002).

Burger (2002) reports that according to The Media Yearbook of South African Rates and Data, there are 300 hundred consumer magazines, and more than 500 trade, technical and professional publications available.

Magazines and newspapers are sold on the street, in shops and cafés, and also door-to-door (Burger, 2002). Subscriptions to these publications are delivered by mail. 
Most of the bigger publications have on-line websites. In South Africa 600 'net-zines' alone are listed as online publications (Burger, 2002). Most of the major newspapers, both national and international are available on-line, with some providing full-text, and some only selected articles or brief headlines. Access could be through the newspaper's or magazine's own webpage or through a vendor or portal. Some, like the Mail and Guardian, even provide archived materials dating back to 1994 (Behrens, 2000).

Two popular South African portals are IOL. Independent Newspapers (http://www.iol.co.za) and News24 (http:// www.news24.com). Independent Newspaper Online ( $\mathrm{OL})$ is a web-based electronic newspaper providing local and international news and other news articles published in the various newspapers. The articles are selected from 14 different newsrooms as well as international wire services. Other than the articles it contains photographs and illustrations. News 24 provides free access to news and magazine-type information, and provides links to publications published by Media24 (Behrens, 2000).

For access to newspapers and periodicals worldwide a website like AJRNewslink (http://ajr.newslink.org) can prove invaluable as it provides instant access to many international information sources.

\section{The Internet}

Other than the myriad of information sources available to parliamentarians via the Internet, specific useful sites were built to fill the need for South African government and legal information. A few popular examples include:

\section{Government Communications and Information System}

To facilitate communication between the government and the public, a government communications agency, the Government Communication and Information System (GCIS), was established. This information, both available through the website (http:// www.gcis.gov.za) or in hard copy format, provides invaluable information to parliamentarians (Molawa, 200I).

The GCIS website provides access to various publications, most notably the annually published South African Yearbook - the only official source of reference in the country - and the Bua Magazine aiming at encouraging debate and promoting government communications. Other publications include:

- GCIS tenders

- Bua Magazine

- Diary of Government Activity

- Government Communicators' Handbook

- Profile containing CV's of government role-players in alphabetical order according to surname

- Annual reports (1998 - 1999)

- Government Communication (GCIS, 2003)

Importantly, three directories are published and regularly maintained, i.e.

- The South African Government Directory (SAGD) containing contact details of Government officials at national and provincial level, as well as those of Government bodies, structures and task groups

- The Directory of Contacts (DOC) containing contact details of foreign embassies in South Africa, South African Embassies abroad, international, business and professional organisations, as well as political parties and legal deposit libraries

- The Media Directory containing contact information of South African media organisations, foreign media in South Africa, community radio stations, local community newspapers, and freelance journalists in South Africa (Molawa, 200I:4).

To provide information about government departments, provinces and other government bodies, the GCIS created two websites linked to their website: South African Government Online (http://www.gov.za) and Parliament South Africa (http:www.parliament.gov.za).

\section{Parliament South Africa (http:www.parliament.gov.za)}

This website includes links to sites of government departments, provinces and other government bodies; organisational information (such as the mission, vision, functions, organisational structure, role-players, and contact information); government documents and publications; speeches and press releases by government players; the Government Tender Bulletin; national symbols; provincial and local government information; and information on South Africa (Molawa, 200I). The site also provides information on the committee meetings of the day, the parliamentary programme of the day, order papers and daily press releases.

This website provides access to the Library of Parliament's Intranet. 
South African Government Online (http://www.gov.za)

This is another extremely useful site, maintained by GCIS. It provides access to a variety of topical information sources, like information on the Presidency, Ministers, Deputy Ministers, Government Departments, Documents, Reports, Forms, Speeches, Provincial and Local Government, key issues, Travel and Tourism, and so on. Full contact details and full text documents are supplied. Forthcoming events are displayed well in advance.

Polity (http://www.polity.org.za)

This initiative provides access to parliamentary information like notices and regulations, policy documents, speeches, budget information and news in review.

\section{Government Departments}

With the exception of three Departments all the Government Departments have a website available where useful information can be gained. The following table provides some insight into the kind of information offered on these websites:

Table 3 Government Departments homepage evaluation (14/05/2003)

\begin{tabular}{|c|c|c|c|c|c|c|c|c|c|c|c|c|c|}
\hline $\begin{array}{l}\text { Department and } \\
\text { homepage address }\end{array}$ & 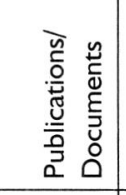 & 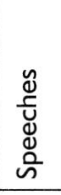 & 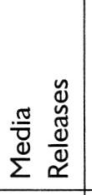 & 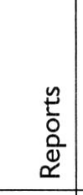 & 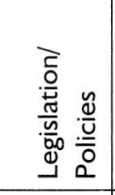 & $\stackrel{\tilde{s}}{\stackrel{s}{\Xi}}$ & 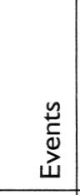 & $\underset{4}{\stackrel{\alpha}{\alpha}}$ & $\stackrel{\stackrel{0}{\pi}}{\Sigma}$ & 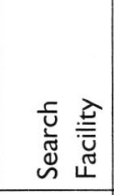 & 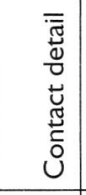 & 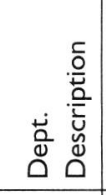 & 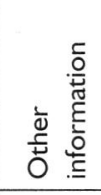 \\
\hline $\begin{array}{l}\text { Agriculture } \\
\text { www.nda.agric.za }\end{array}$ & & & & & & s & & & & & & , & , \\
\hline $\begin{array}{l}\text { Arts and Culture } \\
\text { www.dac.gov.za }\end{array}$ & & & & s & $s$ & 3 & 3 & 3 & & & , & $s$ & . \\
\hline $\begin{array}{l}\text { Communications } \\
\text { www.docweb.pwv.gov.za }\end{array}$ & 3 & & & & & 3 & & & د & s & , & & s \\
\hline $\begin{array}{l}\text { Correctional Services } \\
\text { www.dcs.gov.za }\end{array}$ & & , & & & & & s & & & & , & , & , \\
\hline $\begin{array}{l}\text { Defense } \\
\text { www.mil.za }\end{array}$ & 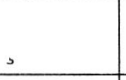 & & & $د$ & & s & & & & 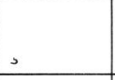 & & , & , \\
\hline $\begin{array}{l}\text { Education } \\
\text { Education.pwv.gov.za }\end{array}$ & 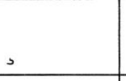 & د & & s & s & 3 & s & & & & & $s$ & s \\
\hline $\begin{array}{l}\text { Environmental Affairs and Tourism } \\
\text { www.environment.gov.za }\end{array}$ & s & s & & د & , & د & s & & & & د & د & د \\
\hline $\begin{array}{l}\text { Foreign Affairs } \\
\text { www.dfa.gov.za }\end{array}$ & , & & & & & , & & & & & & , & , \\
\hline $\begin{array}{l}\text { CGIS } \\
\text { www.cgis.gov.za }\end{array}$ & & , & & & & , & s & s & & & & , & , \\
\hline $\begin{array}{l}\text { Health } \\
\text { www.doh.gov.za }\end{array}$ & $s$ & & & & & 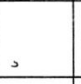 & & & & s & $s$ & , & , \\
\hline $\begin{array}{l}\text { Home Affairs } \\
\text { Home-affairs.pwv.gov.za }\end{array}$ & s & د & & & & s & & 3 & 3 & & د & s & , \\
\hline $\begin{array}{l}\text { Housing } \\
\text { www.housing.gov.za }\end{array}$ & & & & & , & , & & & & & s & , & ב \\
\hline $\begin{array}{l}\text { Independent Complaints } \\
\text { Directorate } \\
\text { www.icl.gov.za }\end{array}$ & د & , & & & 3 & , & & & & & s & , & s \\
\hline $\begin{array}{l}\text { Justice and Constitutional } \\
\text { Development } \\
\text { www.doj.gov.za }\end{array}$ & $s$ & , & & & 3 & $s$ & & & & , & , & , & , \\
\hline $\begin{array}{l}\text { Labour } \\
\text { www.labour.gov.za }\end{array}$ & s & 3 & & s & s & & , & & & & & , & , \\
\hline $\begin{array}{l}\text { Land Affairs } \\
\text { land.pwv.gov.za }\end{array}$ & & 。 & & & & د & & & $s$ & s & s & & , \\
\hline $\begin{array}{l}\text { Minerals and Energy } \\
\text { www.dme.gov.za }\end{array}$ & & 3 & & & & s & s & & & s & $s$ & s & , \\
\hline $\begin{array}{l}\text { National Intelligence Agency } \\
\text { www.nia.org.za }\end{array}$ & & & & & 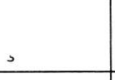 & , & & s & s & & $s$ & s & s \\
\hline $\begin{array}{l}\text { National Treasury } \\
\text { www.treasury.gov.za }\end{array}$ & s & s & & & s & 3 & & & & s & s & 3 & s \\
\hline $\begin{array}{l}\text { Provincial and Local government } \\
\text { www.dplg.gov.za }\end{array}$ & د & د & & & & s & s & & & & & & \\
\hline
\end{tabular}




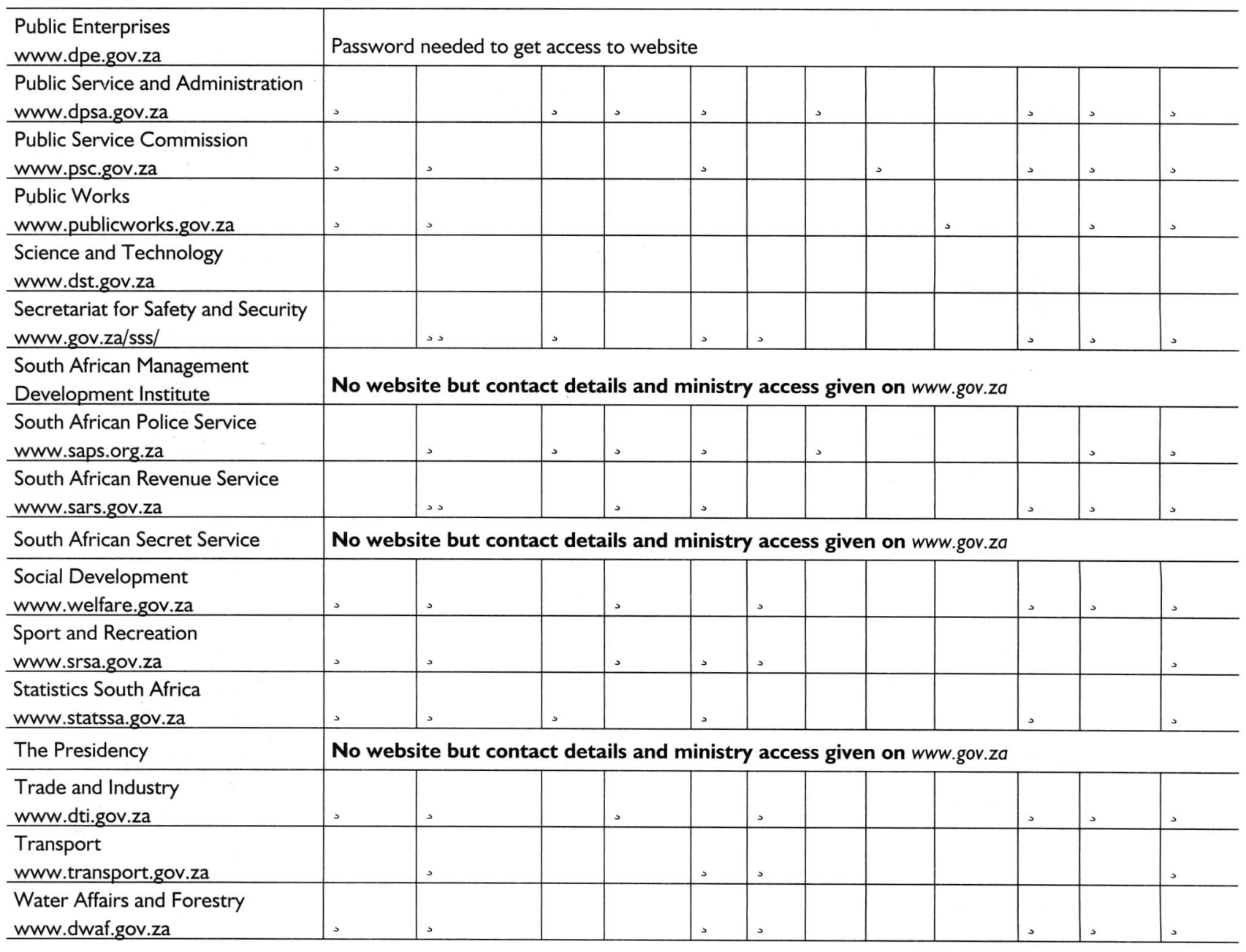

The Government Department website provides full text to documents, policies, speeches, reports and media releases. All the websites also contain information specific to their Department's programmes or services. Very useful features of the majority of the websites are the contact details provided, as well as the links provided to other applicable websites dealing with the issues at hand. This option can save parliamentarians time in having to search on their own for information.

\subsection{The sector concerned with information technology}

South Africa has an extensively developed telecommunications system (Africa South of the Sahara, 200I). According to the Yearbook of South Africa 2002/2003 the total number of telephone lines installed by the end of March 2002, totalled 4.96 million, providing a teledensity of I:I 3 (Jensen, 2002). Other services included the installation of $70788 \mathrm{I}$ fixed-line prepaid lines, 195399 payphones and 467518 Integrated Services Digital Network channels (Burger, 2002). Mobile phone sales totaled 15 million in 2003 and is expected to grow to 21 million in 2006 (Burger, 2004). With a population estimated at 42 million this provides for a current teledensity of $\mathrm{I}: 3$. Between the three major mobile phone networks in South Africa, Vodacom, MTN and Cell C $95 \%$ of the population are covered by their infrastructure.

According to Burger (2004) and (Jensen, 2002 ) a study done by World Wide Worx in 2001 determined that 2,89 million South Africans ( I out of every I5) have access to the Internet. It was estimated that this total will have grown to 3.I million at the end of 2002, making South Africa the largest Internet consumer in Africa and the I $7^{\text {th }}$ largest consumer worldwide. In an effort to facilitate e-government, the government through the Department of Communications engaged in the installation of Public Internet Terminals (PIT). This entails the installation of Internet kiosks in Post Offices countrywide (Burger, 2002). Smart card technology is being used to gain access to the PIT's.

A check on the Internet, using e-mail addresses as an indication of having access to the Internet has revealed that a large majority of all parliamentarians in the National Assembly and NCOP, as well as several Members of the Provincial Legislatures, e.g. Gauteng and Western Cape have access to the Internet. A study done by Mostert (2004) has also revealed that $57 \%$ ( 167 respondents) of parliamentarians have home computers linked to the Internet. 


\section{Discussion}

The four categories of information sources, services and systems manifest a vibrant information society in South Africa. Democratic liberation in South Africa has eliminated censorship emanating into the implementation of one of the most liberal publication policies in the world, against a background of most of the African countries that are still plagued by stringent censorship rules, poor publication outputs and poor bibliographic control (Burger, 2002)..

South Africa has a burgeoning publishing trade dating back from 1824 (Muller, 1968) with many publishing houses actively involved in the publishing trade. These publishing houses are of both local or international nature, freely selling their products in a myriad of shops, cafes or through street vendors.

The tracing of the information sector has revealed that despite the fact that the information sources, services and systems are widely dispersed throughout the country, access to the majority are available via telephone, fax, the Internet or by way of a personal visit. A well developed bibliographic control system such as SABINET Online, SAIS, as well as electronic catalogues of various information services contributes to access to the majority of publicly available information sources in the country. Parliamentarians, by nature of their parliamentary library's subscription to SABINET Online and SAIS have unrestricted access to the information sources available through the systems, either via the library itself or by using their own Internet connections.

Both the literature review and the search on the Internet provided a clear picture of the variety of information systems and services available to parliamentarians. Currently a whole host of libraries such as public-, school-, special libraries, or libraries in Higher Education institutions are available in the majority of townships, towns and cities throughout the countries. Museums and archives covering a variety of topics also were found to be easily accessible, even by electronic means. Distance from an information system or service therefore cannot be seen as a hindrance any longer. Any parliamentarian with the necessary will, skills and knowledge could contact them with information requests.

The Internet search revealed the extent to which technology could be utilized to access information sources, services and systems. The majority of these indicated well-developed websites that could assist in answering a wide scope of requests by using the options provided on the websites. Alternatively, contact information such as telephone and fax numbers, or email addresses are supplied.

A study done by Mostert (2004) found that Internet access amongst a group of 167 parliamentarians was as high as $78 \%$. This included both access from home or via their offices. Compared with Internet access of $14 \%$ in Ghana (Alemna and Skouby 2000), and $73 \%$ by Members of the House of Commons in the United Kingdom (Serema 1999) this figure of $78 \%$ is very high. Sixty three percent of the respondents indicated that they actually utilized the Internet.

The growing importance of the Internet as a tool to access information sources, services and systems amongst parliamentarians was confirmed during the interviews with staff from the Library of Parliament, Cape Town. It was pointed out that in reaction to the increased utilization of Internet by parliamentarians, a website was initiated by the Library of Parliament to serve as a portal to relevant information sources. This is a good example of how an information service does assist parliamentarians to easily access information.

\section{Conclusions}

The study identified specific information needs expressed by the parliamentarians. Though the major needs reflected the governmental nature of their work environment, a wide range of topics was also identified as information needs. It can be expected of parliamentarians to take decisions based on available and current information. Marcella, Carcary and Baxter (1999) point out that the decision-making process relies on judgments or choices to be made. This is only possible when options are provided to base a decision on.

South Africa has been identified as a relatively information-rich country with liberal censorship rules, thus making it possible for parliamentarians to search for information on an extensive basis. The extensive information industry identified in the study should potentially enable parliamentarians to make informed choices. Availability however does not necessarily signify accessibility. Accessibility and utilization of the sources, services and systems could be dependent on factors such as the information seeking skills of the parliamentarian, knowledge of the existence of the sources, services and systems, and available time to do the searching. It is therefore recommended that parliamentarians be sensitized about existing information sources, services and systems which can be used to satisfy their information needs, should they prefer to seek for the information on their own. However, to overcome the lack of time parliamentarians should also be made aware of professional information intermediaries, such as librarians and researchers within their work environment, who could act as gatekeepers between them and the information needed. In this manner parliamentarians could easily channel their information requests to the gatekeeper, who could access, retrieve and disseminate the needed information to the parliamentarian. This could create a win-win situation between the parliamentarian's need for relevant information, and the viability of the gatekeeper's role as information provider. 


\section{REFERENCES}

Adeyemi, N.M. 1991. Issues on the provision of information services in developing countries. African journal of libraries, archives and information science, $\mathrm{I}(\mathrm{I}): \mathrm{I}-8$.

Africa South of the Sahara. 200I. $30^{\text {th }}$ ed. London: Europa Publishers.

Alemna, A.A. and Skouby, K.E. 2000. An investigation into the information needs and information-seeking behaviour of members of Ghana's legislature. Library Management, 21 (5):235-240.

Behrens, S.J. 2000. Bibliographic control and information sources. $3^{\text {rd }}$ ed. Pretoria: Unisa Press.

Boon, J.A. 1992. Information and development: towards an understanding of the relationship. South African Journal for Library and Information Science, 60(2):63-72.

Bredenkamp, N. 1995. Ineffectiveness of information transfer to developing communities. Meta-info bulletin, 4(3):6-10.

Britz, J.J, Boon, J.A. and De Lange, M. 1993 The development of a method to determine the size of the information sector in South Africa. South African Journal for Library and Information Science, 6I (2):6I-67.

Burger, D. ed. 2004. South Africa Yearbook 2003/04. $7^{\text {th }}$ ed. Retrieved on March 19, 2004 from the website: http://www.gcis.gov.za/docs/ publications/yearbook.htm.

Burger, D ed. 2002. South Africa Yearbook 2002/03. $6^{\text {th }}$ ed. Pretoria: Government Communication and Information System.

Burgers, M. 2003. Interview at the Library of Parliament, Cape Town on April I5, 2003

Calitz, G.J. (n.d) Introducing archives and the National Archives of South Africa. Pretoria: Department of Arts, Culture, Science and Technology.

The Europa World Yearbook 200I. 200I. 42 $2^{\text {nd }}$ ed. v.ll .London: Europa Publishers.

De Lange, M.A. Boon, J.A. and Britz, J.J. 1993. Information sector: a critical review of selected readings with specific reference to South Africa. South African Journal for Library and Information Science,6I (I): I-9.

DOOR online. n.d. Retrieved on March 4, 2004 form the website: http://www.dooronline.org/glossary.pl?!.

Faye, M. 1995. The Pan African Development Information System (PADIS) of the UN

Economic Commission for Africa: part 2. Meta-info bulletin, 4(3):15-18.

GCIS. 2003. Government Communication Information System. Retrieved on May 5, 2003 from the website: http:// www.gcis.gov.za.

The Government Information Locator Service (GILS). 1994. Retrieved on March 4, 2004 from the website: http://www.glis.net/ gilsappb.htm.

Hendrikz, F. (n.d) The book chain in South Africa. Retrieved on May 12, 2003 from the website: http://www.inasp.info/pubs/ bookchain/profiles/South Africa.html.

Jensen, M. 2002. The African Internet - a status report. Retrieved Octobr I, 2003 from the website http://www3.wn.apc.org/ africa/afstat.html.

Kaniki, A.M. 1992. Meeting the needs of agricultural researchers in Africa: the role of unpublished reports. Information development, 8(2):83-89.

Marcella, R, Carcary, I and Baxter, G. 1999. The information needs of United Kingdom Members of the European Parliament (MEPs). Library Management, 20(3): 168-178.

Mchombu, K.J. 1993. African information services: the search for a role. Paper presented at the Info Nova Conference, Pretoria, May 1993.16p.

Molawa, S. 200I. The role of the Government Communication and Information System (GCIS) in rendering government information services. Meta-infoBulletin, 10(3):3-6.

Mostert, B.J. 2004. Parliamentary information sources, systems and services in South Africa and the role of parliamentary libraries in information provision. (Ph.D thesis - unpublished). KwaDlangezwa: University of Zululand.

Mostert, B.J. 1997. Community libraries: the concept and its application: with particular reference to the Pinetown Community Libraries. (M.Bibl-thesis). KwaDlangezwa: University of Zululand.

Otike, J.N. 1989. Indigenous materials in libraries and Information centres in Kenya.Collection Management, II(I/2): 199-2I5.

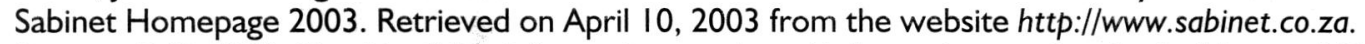

Serema, B.C. 1999. Matching MP's information needs and information services in the House of Commons. Library Management, 20(3): 179-189

Sturges, P \& Neill, R. 1990. The quiet struggle: libraries and information for Africa. London: Mansell.

Thapisa, A. P. N. 1996. "Legislative Information Needs of Indigenous Parliamentarians in Botswana and Impact of effective decision making". International Information \& Library Review, 28: 203-232. 